\title{
STRATEGI IMPLEMENTATION OF TOTAL QUALITY MANAGEMENT IN EDUCATION INSTITUTIONS
}

\author{
Yasnimar Ilyas
}

\begin{abstract}
In education sector, Total Quality Management is philosophy about sustainable improvement, that is contribute a practice tool to each educational institution to cover needs, wills and hopes of consumer's satisfaction. The main word wich is involved with Total Quality Management is continous improvement and quality improvement. Total Quality Management is one of management strategy to response external challenges to cover consumer's satisfaction.

Fundamental; Total Quality Management consist of two basic aspect:

1. Quality Manajemen System-QMS

2. Continous Quality Improvement-CQI

In case to make implementation management concept, the strategy which is able to implement by education institution is evaluation to analyze strongness and weekness. Based on that evaluation, the educational institution and all it's stakeholder consider and formulate quality target.

The next step is to adjust planning including cost that refers to priority scale and national policy and depend on condition and resources each educational institution. In arranging program, the educational institution must define indicators or quality target. The most important step is monitoring and final evaluation. In monitoring, implementation of program is compared with the quality target defined before and also with the cost planning. The result of this evaluation can be used to adjust planning in the future. This process is a sustainable process.
\end{abstract}

Keywords: Total Quality Management, ISO 9000, eduacational instutional.

\section{INTRODUCTION}

Improving the quality of human beings to be able to compete in a global world is largely determined by the quality of education. Therefore, the deployment of the education sector is an important concern that the establishment of an educational process to produce high quality graduates.

In the educational context of Integrated Quality Management (Total Quality Management) is a methodology philosophy of continuous improvement, which can provide a set of practical tools to every educational institution to meet the needs, desires and expectations of customers, current and future. (Edward Sallis, 2006: 73)

A quality management system is a set of documented procedures and standard practices for management system that aims to ensure the suitability of the process and products and the specific needs or requirements. It needs or requirements defined or specified by the customer and the organization.

Factors management will greatly determine the productivity and effectiveness of educational institutions, in addition to many other Factor. Education as a system will not be able to produce high quality output and outcome, if the educational process is not managed well. Therefore education should be managed professionally, to be able to compete and be able to compete to answer all the global challenges faced. In order to attempt to improve the 
productivity and effectiveness, educational institutions must constantly carry out improvement by always taking into account internal factors internal (inside) and external (outside). One outside factor to consider is the quality approaches that come from the world of industry and business, such as Total Quality Management (TQM).

\section{Through the Education Quality Assurance Quality Management System ISO 9001: 2000}

Definition of quality according to ISO is a comprehensive overview and characteristics of goods or services, which shows his ability and satisfying specified or implied (Bandung Institute of Management Assistance, 2000: 11)

Quality Management System ISO 9001: 2000 is used as a tool for quality assurance of education. Quality Management System ISO 9001: 2000 is a management systems approach to the process and focusing on customer satisfaction or it can be interpreted that the quality management system is a strategic management system integrated involving all staff to continuously improve the processes within the organization in order to meet the needs, desires, and expectations of customers. Educational institutions which implemented Quality Management System ISO 9001: 2000 is expected to guarantee and ensure quality education providers independently and take corrective actions as well as continuous quality improvement.

Educational organizations that implemen using the Quality Management System ISO 9001: 2000 must develop the appropriate organizational structure of business processes run educational institutions to produce products / graduates who fit the needs of learners satisfaction. Business process provides linkage of all processes to produce graduates and prepared with quality manuals, procedures and work instructions that recomendation and recorded if it has been implemented and become activity recorded evidence material to do both internal and external audit. The results of the audit findings are used to improve our delivery of education and continuous improvement based on objective data and facts corresponding customer satisfaction survey.

\section{Build-Based Education Management ISO 9000}

According Sugiyono (2003: 15), the failure of education to build human resources in Indonesia are caused by the management of education in Indonesia has not been done professionally. Furthermore, Sugiyono (2003: 21) states management of vocational education professionals is the intelligent management, the management is able to carry out the functions of management (planning, doing, checking, reviewing) are sunggung-indeed, consistent and sustainable resource management includes 7M (man, money, materials, methods, mechine, market and minute), so that the objectives of vocational education can be achieved effectively and efficiently.

To get to the professionalism of the management of education will require a recognized quality management system and standardized both nationally and even internationally. Of the quality management system of international standard is ISO 9000: 2000 (see ISO 9000 version 2000). ISO 9000 as a quality management system is not only applied to the product manufacturing industry, but also according to industry services such as educational institutions. Some educational institutions have started to implement a quality management system ISO 9000 and even some of which have been awarded ISO 9000. 
According to ISO gives description and characteristics of goods services, which showed ability to satisfy the needs of the specified or implied (Bandung Institute of Management Assistance, 2000: 11). According to some experts quoted by Sprint Consultant (2002: 5) is:

a. According to the usefulness (Fitness For Use-J.M Juran),

b. Meet customer requirements (Confrom to Customer Requirement-Philip B Crosby),

c. Meet customer expectations (Meeting Customer Expectation-A. V Fegenbaum-A. V Fegenbaum)

d. Customer satisfaction (Customer Satisfaction-K. Ishikawa)

From the definition of quality, to achieve a good quality of the education providers have to recognize who are the customers. By recognizing our customers can specify the quality to be achieved to meet customers' satisfaction.

\section{Strategi Implementation Total Quality Management TQM in Education Institution}

To create a quality educational institution as expected a lot of people or a community, not just the responsibility of the educational institution, but it is the responsibility of all parties and the business world as an internal and external cutomer of an educational institution. Integrated Quality Management (Total Quality Management) in the context of education is a philosophy of the methodology of improvement on an ongoing basis, to provide a set of practical tools to every instituisi education to meet the needs, desires and expectations of customers, current and future (Edward Sallis, 2006: 73). While Santoso said that Total Quality Management is a management system that elevates the quality as a business strategy that is oriented to customer satisfaction by involving all members of the organization (2003: 4). Total Quality Management is an approach to run a business that tries to maximize organizational competitiveness through continuous improvement of the products, services, people, labor, process, and environmental (M.N Nasution, 2004: 18).

According to the Indonesian National Standard (SNI ISO 9001: 2000), the organization should have document, implementation, maintain a quality management system and continually improve its effectiveness according to standards required, for the organization must:

a. Determine the process specified for the quality management system and their application throughout the organization,

b. Determine the sequence and interaction of these processes,

c. Establish criteria and methods needed to ensure that both the operation and control of the process is effective,

d. Ensuring the availability of resources and information necessary to support the operation and monitoring of the process,

e. Monitor and measure where applicable and analyze these processes, and implement the actions necessary to achieve planned results,

f. Continuous correction of the process.

In the implementation of these management concepts, strategies that can be implemented by educational institutions, among others, includes a self-evaluation to analyze the strengths and weakness of the institution. Based on the evaluation of the education agency together all parties and communities determine the vision and mission of educational institutions in improving the quality of education or formulate quality expected and continued with the planning program educational institutions, including financing, with reference to priorities and national policy in accordance with the conditions educational institutions and the 
resources available. In preparing the program, the institution must have quality indicators or targets to be achieved. Another important things are monitoring and evaluation of programs that have been planned periodically, in accordance with the funding to see the achievement of the vision, mission, and goals that have been established in accordance with national policy and quality targets are achieved and reported the results to the public and the government. Results of the evaluation (process and output) this can then be dipergunkan as input for the planning / programming of educational institutions in the future (next year). Thus continuously as a continuous process.

If it is associated with a process model of ISO 9001: 2000 consists of five main sections that describe the organization's management system are:

1. Quality Management System

2. Management Responsibility

3. Management Resources

4. Actual Education Activity

5. Measurement, Analysis, Improvement

Then it can be described as follows:

If all five processes of Quality Management System ISO 9001: 2000 is applied in educational institutions have met the requirements and achieve the target as expected, it is thus customer satisfaction has been met.

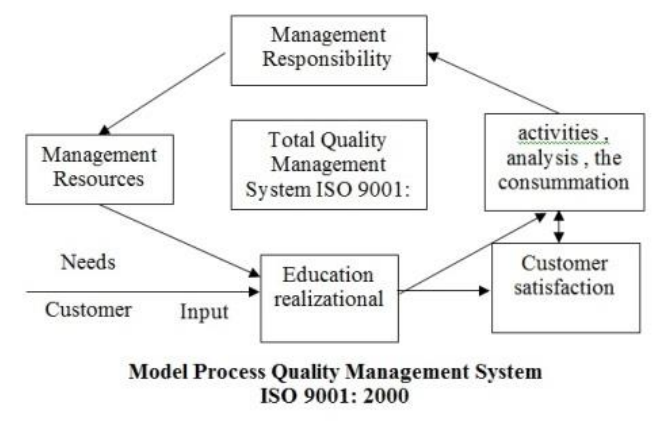

\section{REFERENCES}

Vincent, Gasperst. 2003. ISO 9001:2000 and Continual Quality Improvement. PT Gramedia Pustaka Utama. Jakarta.

Zuhrawaty,. 2002. Panduan dan kiat sukses menjadi auditor ISO 9001. Media Pressindo. Yogyakarta.

Seminar. 2007. The Move From Conformance to Performance Exxellence. Bika Solusi Perdana. Jakarta.

http://massofa.wordpress.com/2008/01/24/mendongkrak-mutu-sekolah-dasar/ yang diakses pada tanggal 20 Juni 2010

Kamil, S.S., M.Pd. Penjamin Mutu Pendidikan Melalui Sistem Manajemen Mutu ISO 9001:2000. Wakil Manajemen Mutu LPMP. Lampung

Lembaga Bantuan Manajemen Bandung (2000); Pengenalan ISO 9000; Hand Out Materi Pelatihan ISO 9000; Yogyakarta, 2000

Spint Consultant (2000); Kesadaran Mutu ISO 9000; Makalah Seminar Kesadaran Mutu; Yogyakarta, 2002.

Sallis, Edward. 1993, Total Quality Management in Education. London: Kogan Page Educational Series.

Dikmenum, 1999, Peningkatan Mutu Pendidikan Berbasis Sekolah: Suatu Konsepsi Sekolah (paper kerja), Depdikbud, Jakarta.

Fattah, Nanang. 1999. Landasan Manajemen Pendidikan. Bandung: Remaja Rosda Karya. 